\title{
Genetic markers of inflammation may not contribute to metabolic traits in Mexican children.
}

Neeti Vashi, Carolina Stryjecki, Jesus Peralta-Romero, Fernando Suarez, Jaime Gomez-Zamudio, Ana I. Burguete-Garcia, Miguel Cruz, David Meyre

Background. Low-grade chronic inflammation is a common feature of obesity and its cardio-metabolic complications. However, little is known about a possible causal role of inflammation in metabolic disorders. Mexico is among the countries with the highest obesity rates in the world and the admixed Mexican population is a relevant sample due to high levels of genetic diversity. Method. Here, we studied 1462 Mexican children recruited from Mexico City. Six genetic variants in 5 inflammation-related genes were genotyped: rs1137101 (LEPR), rs7305618 (HNF1A), rs1800629 (TNFA), rs1800896, rs1800871 (IL-10), rs1862513 (RETN). Ten continuous and eight binary traits were assessed. Linear and logistic regression models were used adjusting for age, sex, and recruitment centre. Results. We found that one SNP displayed a nominal evidence of association with a continuous trait: rs1800871 (IL-10) with LDL (beta $=-0.068 \pm 1.006, P=$ 0.01). Subsequently, we found one nominal association with a binary trait: rs7305618 $(H N F 1 A)$ with family history of hypertension (odds-ratio $=1.389$ [1.054-1.829], $\mathrm{P}=0.02$ ). However, no P-value passed the Bonferroni correction for multiple testing. Discussion. Our data in a Mexican children population are consistent with previous reports in European adults in failing to demonstrate an association between inflammation-associated SNPs and metabolic traits. 
1 Genetic markers of inflammation may not contribute to metabolic

2

\title{
traits in Mexican children
}

\author{
Neeti Vashi' ${ }^{1}$, Carolina Stryjecki ${ }^{1}$, Jesus Peralta-Romero², Fernando Suarez ${ }^{2}$, Jaime $^{2}$
}

Gomez-Zamudio², Ana I. Burguete-Garcia³, Miguel Cruz ${ }^{2, *}$, David Meyre ${ }^{1,4, *}$

${ }^{1}$ Department of Clinical Epidemiology and Biostatistics, McMaster University, Hamilton, ON, Canada; ${ }^{2}$ Medical Research Unit in Biochemistry, Hospital de Especialidades, Centro Médico Nacional Siglo XXI del Instituto Mexicano del Seguro Social, Mexico City, Mexico; ${ }^{3}$ Centro de investigación sobre enfermedades infecciosas. Instituto Nacional de Salud Pública. Cuernavaca, Morelos, Mexico; ${ }^{4}$ Department of Pathology and Molecular Medicine, McMaster University, Hamilton, ON, Canada.

Running title: SNPs, inflammation and metabolism

Corresponding author*: Dr. David Meyre. Department of Clinical Epidemiology and Biostatistics, McMaster University, Room 3205, Michael DeGroote Centre for Learning \& Discovery, 1280 Main Street West, Hamilton, ON L8S 4K1, Canada. Tel: 905.525.9140 Ext. 26802. Fax: 905.528.2814. Email: meyred@mcmaster.ca. Dr. Miguel Cruz, Unidad de Investigación Médica en Bioquímica, Hospital de Especialidades Centro Médico Nacional Siglo XXI, Instituto Mexicano del Seguro Social, Av. Cuauhtémoc, 330 C.P. 06725, México, D.F. Tel: 5255 57612358; Fax: 5255 56276914. Email: $\underline{\text { mcruzl@yahoo.com. }}$ 
24 Abstract

25 Background. Low-grade chronic inflammation is a common feature of obesity and its cardiometabolic complications. However, little is known about a possible causal role of inflammation in metabolic disorders. Mexico is among the countries with the highest obesity rates in the world and the admixed Mexican population is a relevant sample due to high levels of genetic diversity. Method. Here, we studied 1462 Mexican children recruited from Mexico City. Six genetic variants in 5 inflammation-related genes were genotyped: rs1137101 (LEPR), rs7305618 (HNF1A), rs1800629 (TNFA), rs1800896, rs1800871 (IL-10), rs1862513 (RETN). Ten continuous and eight binary traits were assessed. Linear and logistic regression models were used adjusting for age, sex, and recruitment centre.

Results. We found that one SNP displayed a nominal evidence of association with a continuous trait: rs1800871 $(I L-10)$ with LDL (beta $=-0.068 \pm 1.006, \mathrm{P}=0.01)$. Subsequently, we found one nominal association with a binary trait: rs7305618 (HNF1A) with family history of hypertension correction for multiple testing.

Discussion. Our data in a Mexican children population are consistent with previous reports in European adults in failing to demonstrate an association between inflammation-associated SNPs and metabolic traits. 


\section{Introduction}

48

49

50

51

52

53

54

55

56

57

58

59

60

61

62

63

64

65

66

67

68

69

Obesity has increased rapidly in prevalence over the last 30 years causing a growing public health burden at the worldwide level(Ogden et al. 2010). Obesity is no longer only a concern for high income countries, but is escalating in developing countries as well(Hossain et al. 2007). Even more concerning are the increasing rates of childhood obesity which have tripled over the last 30 years(Ogden et al. 2010). In 2011-2012, the age-adjusted prevalence of obesity in adults from the United States of America was 47.8\%, 42.5\%, 32.6\% and $10.8 \%$ in nonHispanic Blacks, Hispanics, non-Hispanic White Americans, and non-Hispanic Asians, respectively(Ogden et al. 2014). These discrepancies may be due to differences in diet, lifestyle, socioeconomic status and access to health care across ethnic groups. However they may also reflect differences in the genetic susceptibility to obesity and metabolic disorders as evidenced by admixture studies(Norden-Krichmar et al. 2014). Twin studies have reported heritability estimates between 47-90\% for body mass index (BMI)(Elks et al. 2012). Eleven monogenic genes and more than 140 polygenic loci have been identified to date, accounting for a modest fraction of the heritability of obesity(Locke et al. 2015b; Yazdi et al. 2015). Obesity is associated with cardio-metabolic complications (insulin resistance, type 2 diabetes, hypertension, dyslipidemia, cardiovascular disease) that cluster into the so-called metabolic syndrome(Walker et al. 2012). However, the relationship between obesity and associated complications is complex as obesity does not always convert into a metabolic syndrome (Karelis et al. 2004; Kramer et al. 2013). Consistent with the phenotypic correlations seen in observational epidemiology, shared genetic contributions between the components of the metabolic syndrome suggest that shared molecular roots may be involved in the development of the metabolic syndrome(Avery et al. 2011; van Vliet-Ostaptchouk et al. 2013; Vattikuti et al. 2012). 
71 linking obesity to other metabolic complications(Hotamisligil 2006). Inflammation can be defined as a protective response of an organism to infection and injury. This operates through

73 initiating a healing process of pathogen killing and tissue repair to restore homeostasis at the infected and/or damaged sites(Hotamisligil 2006). Normally, the inflammatory response to

75 harmful stimuli is short-lived and once the damage is removed or neutralized, the inflammation

76 is resolved through negative feedback mechanisms(Hotamisligil 2006). However, inflammatory

77 response that fails to regulate itself becomes chronic and is believed to set the stage for a broad 78 range of diseases(Hotamisligil 2006). Obesity and its cardio-metabolic complications are

associated with low-grade chronic inflammation, characterized by abnormal cytokine production, activation of a network of inflammatory signal pathways, and new connective tissue formation(Wellen \& Hotamisligil 2005).

Genome-wide association and in a lesser extent candidate gene studies identified around fifty common genetic variants associated with serum inflammatory biomarker levels (e.g. Creactive protein (CRP), soluble Intercellular Adhesion Molecule 1 (sICAM-1), interleukin-6 (IL6) or soluble P-selectin)(Raman et al. 2013). Researchers then used these recently discovered genetic variants to determine whether this chronic inflammation is a cause of obesity and other metabolic disorders, or a consequence of it. Overall, Mendelian randomization experiments including gene variants in inflammation pathways did not evidence a causal role of inflammation in obesity or type 2 diabetes(Brunner et al. 2008; Rafiq et al. 2008; Welsh et al. 2010) and conflicting results about a causal link between inflammation and cardiovascular disease have been reported(Brunner et al. 2008; Consortium 2012; Raman et al. 2013; Varbo et al. 2013). At 
92 this stage, more research is needed to understand the role of inflammation in the development of 93 obesity and cardio-metabolic complications, particularly in non-European populations.

Metabolic syndrome is observed in childhood obesity, but can also develop in lean

95 children, suggesting that obesity is a marker for the syndrome, not a cause(Elliott et al. 2009). Since obesity and its complications are associated with atherogenesis starting in childhood and early adulthood(Tounian et al. 2001; Weiss et al. 2013), a better understanding of the molecular mechanisms involved in the clustering of cardio-metabolic factors early in life may help to develop more efficient programs to prevent the development of metabolic syndrome.

The Mexican population is characterized by a high prevalence of obesity and metabolic complications. The 2012 National Health and Nutrition Survey indicates that $34.4 \%$ and $71.2 \%$ of the Mexican children and adults respectively are overweight or obese(León-Mimila et al. 2013; Tounian et al. 2001). This ranks Mexico among the countries with the highest obesity rates in the world(Barquera et al. 2009; León-Mimila et al. 2013). The prevalence of metabolic syndrome (ATP III criteria) in children and adolescents living in Mexico was estimated to be $20 \%$ in 2006(Barquera et al. 2009; Castillo et al. 2007). Depending on the definitions used (American Heart Association/ National Heart, Lung, and Blood Institute or the International Diabetes Federation), the prevalence of metabolic syndrome among Mexican adults ranges from 59.7 to $68.7 \%$ (Castillo et al. 2007). This exceptionally high burden of obesity and metabolic syndrome in the Mexican population is largely due to the rapid transition towards an 'obesogenic' environment characterized by a sedentary lifestyle, an increase in the consumption of sugar-sweetened beverages coupled with the recent proliferation of fast food restaurants(Isordia-Salas et al. 2011). However, the tremendous genetic variety and unique genetic architecture of the admixed Mexican population may partly account for a higher 
115 susceptibility to obesity and metabolic disturbances than in other populations(Rivera et al. 2002).

116 Mexican populations consist of Native individuals as well as individuals of European or African

117 descent(Rivera et al. 2002). The distributions and proportions of these three groups vary with

118 the region studied however evidence shows very few true Natives remain as virtually all native

119 groups show some degree of admixture, mainly with Europeans(Consortium 2014). Thus

120 studying the Mexican population gives insight into the disease mechanisms of a variety of races

121 due to the genetic diversity present in the population(Consortium 2014; Lisker 1996).

122 In this study, we assessed the association of 6 common genetic single nucleotide 123 polymorphisms (SNPs) in 5 inflammation-related genes with 10 continuous and 8 binary 124 metabolic traits in 1462 children from the Mexican population. Our data do not favor an 125 association between inflammatory processes and the development of metabolic complications.

\section{Methods}

\section{Study Participants}

128 A total of 1462 unrelated children aged 6-14 having both genetic and phenotypic data available 129 were included in this study. Children were randomly selected to participate in a cross-sectional 130 study from four schools in Mexico City between July 2011 and July 2012. Anthropometric traits 131 were assessed by a trained pediatrician. Blood samples were collected for biochemical 132 measurements and DNA extraction. Information regarding family history of type 2 diabetes, 133 obesity and hypertension was obtained via questionnaires. The study protocol was approved by 134 the Mexican Social Security Institute National Committee and the Ethical Committee Board and 135 all experiments were performed in accordance with relevant guidelines and regulations. Informed 136 consent was obtained from both parents and the child.

\section{Genotyping}


138 Genomic DNA was extracted from peripheral blood using the FLEX STAR Autogen platform

139 (Holliston, Massachusetts US). The genotyping was performed using the TaqMan OpenArray

140 Real-Time PCR System (Life Technologies, Carlsbad, US), following the manufacturer's

141 instructions. We selected 6 SNPs in or near 5 genes that displayed redundant associations with

142 inflammation-related traits in literature: rs1137101 (leptin receptor (LEPR)), rs7305618

143 (hepatocyte nuclear factor 1 alpha $(H N F 1 A)$ ), rs1800629 (tumor necrosis factor alpha $(T N F A)$ ),

144 rs1800896, rs1800871 (interleukin-10 (IL-10)), rs1862513 (resistin (RETN)) (Kilpelainen et al.

145 2010; Ortega et al. 2014; Raman et al. 2013; Wang et al. 2011). The 6 SNPs showed no deviation

146 from Hardy-Weinberg Equilibrium $(0.22 \leq \mathrm{P} \leq 0.76)$. The call rate for each of the 6 SNPs was

147 comprised between 94.6 and $100 \%$ (Supplementary Table 1). The two SNPs rs 1800896 and

148 rs1800871 in $I L-10$ display modest linkage disequilibrium in the Mexican children study sample

$149(\mathrm{r} 2$ value $=0.239)$.

150 Phenotyping

151 All participants were weighed using a digital scale (Seca, Hamburg, Germany). Height was 152 measured with a portable stadiometer (Seca 225, Hamburg, Germany). Body mass index was 153 calculated as weight $(\mathrm{kg}) /\left(\right.$ height $\left.(\mathrm{m})^{2}\right)$ and classified as underweight, normal weight, 154 overweight, obese according to the Centers for Disease Control and Prevention CDC 2000 155 references. Waist circumference (WC) and hip circumference (HC) were measured at the 156 midpoint between the lowest rib and the iliac crest at the top of the iliac crest respectively, after a 157 normal exhalation with children in the standing position. Systolic and diastolic blood pressure 158 (SBP and DBP) were measured using a mercurial sphygmomanometer (ALPK2, Tokyo, Japan). 159 Blood pressure readings were taken for each participant twice on the right arm in a sitting 160 position with a 5 minute rest between each measurement and the mean of the two readings was 
161 determined. Hypertension was defined as average measured blood pressure above the American

162 Heart Association's recommendations (systolic $\geq 140 \mathrm{mmHg}$ or diastolic $\geq 90 \mathrm{mmHg}$ ). Blood

163 samples were obtained following a 12 hour fast and were analyzed for fasting glucose, total

164 cholesterol (TC), HDL-cholesterol (HDL), LDL-cholesterol (LDL) and triglycerides (TG) using

165 the ILab 350 Clinical Chemistry System (Instrumentation Laboratory IL. Barcelona Spain).

166 Insulin (IU) was measured by chemiluminescence (IMMULITE, Siemens, USA). The 2003

167 ADA criteria for fasting plasma glucose (FPG) were used to classify children as normal (FPG $<$

$1685.6 \mathrm{mmol} / \mathrm{L}$ ), as having impaired fasting glucose (IFG; FPG 5.6- $6.9 \mathrm{mmol} / \mathrm{L}$ ), or as having T2D

169 (FPG $>7.0 \mathrm{mmol} / \mathrm{L})($ Lisker et al. 1996). Subjects with IFG or T2D were considered as having

170 hyperglycemia. Dyslipidemia was defined as fasting triglycerides $\geq 100 \mathrm{mg} / \mathrm{dL}$ (0-9 years of age)

171 or triglycerides $\geq 130 \mathrm{mg} / \mathrm{dL}(10-19$ years of age $)$ and/or HDL-C $<35 \mathrm{mg} / \mathrm{dL}$ and/or LDL-C $\geq$

$172130 \mathrm{mg} / \mathrm{dL}$, according to current recommendations(Kalra et al. 2009). Information regarding

173 family history of type 2 diabetes, overweight / obesity, and hypertension was obtained via 174 questionnaires.

\section{Statistical Analyses}

Statistical analyses were performed using SPSS (version 20). We assessed the power of

177 our sample using QUANTO software version 1.2.4 (University of Southern California, Los

178 Angeles, CA, USA). Non-biological outlier data were discarded. Due to the risk of blood

179 hemolysis, fasting insulin values $<1 \mathrm{mIU} / 1$ were discarded from the study. The normal

180 distribution of continuous variables was tested using the Kolmogorov-Smirnov test. All traits of 181 interest deviated significantly from normality. Logarithmic transformations corrected the lack of 182 normality for fasting insulin, improved the distribution of six traits (BMI, waist and hip 183 circumference, waist to hip ratio, total cholesterol, triglycerides,) despite still deviating from 
184 normality, and did not improve the distribution of fasting glucose, HDL and LDL cholesterol.

185 Linear regression models were used to examine the association between the SNPs and metabolic

186 traits. These tests were adjusted for sex, age and the recruitment centre. Genetic association

187 studies were performed under an additive mode of inheritance for 5 out of 6 SNPs and the effect

188 allele was the minor allele. Because only one AA homozygous carrier was identified for 189 rs1800629 (TNFA), we used a dominant model instead. Two-sided $\mathrm{P}<0.05$ before Bonferroni 190 correction were considered as nominally significant. After applying a Bonferroni's correction for 191 multiple testing (18 binary / continuous traits x 6 SNPs), P-values $<4.6 \times 10^{-4}(0.05 / 108)$ was 192 considered as significant.

193

194

195

196

197

198

199

200

201

202

203

204

205

\section{Results}

\section{Characteristics of the Mexican children population}

The main anthropometric and biological characteristics of the 1462 Mexican children are summarized in Table 1. Fifty-three percent of the population were males. Children exhibited an average age and BMI of $9.24 \pm 2.07$ years and $19.65 \pm 4.20 \mathrm{~kg} / \mathrm{m}^{2}$, respectively. Using the Centers for Disease Control and Prevention 2000 references, $1.4 \%$ of the children were underweight, $49.4 \%$ were normal weight, $21.3 \%$ were overweight and $27.9 \%$ were obese. Additionally, $1.5,3.1$ and $34.9 \%$ of children displayed hypertension, hyperglycemia, and dyslipidemia, respectively. A family history of overweight / obesity, type 2 diabetes or hypertension was reported for 53.0, 12.0 and $16.3 \%$ of children, respectively (Table 1). The sample size was similar for all traits except fasting insulin (data available in $78.5 \%$ of subjects) due to the phenomenon of blood hemolysis.

\section{Association between genetic markers of inflammation and continuous metabolic traits}


206 The associations between the 6 genetic variants of inflammation and 10 continuous metabolic

207 traits are reported in Table 2. Only one SNP displayed a nominal evidence of association:

208 rs $1800871(I L-10)$ with LDL (beta $=-0.068 \pm 1.006, \mathrm{P}=0.010)$.

\section{Association between genetic markers of inflammation and binary metabolic traits}

210 The associations between the 6 genetic markers of inflammation and 8 binary metabolic traits are

211 reported in Table 3. One nominally significant association was found: rs7305618 (HNF1A) with

212 family history of hypertension (1.389 [1.054-1.829] $\mathrm{p}=0.020)$. No P-value was significant after

213 Bonferroni correction for multiple testing.

\section{Discussion}

215 In the present study, we assessed the association of 6 common genetic variants in 5

216 inflammation-related genes with 10 continuous and 8 binary metabolic traits in 1462 children

217 from the Mexican population. We found one nominal associations between a genetic variant and

218 the continuous traits. Subsequently, we only found two nominal associations between genetic

219 variants and continuous / binary metabolic traits. No P-value resisted to a Bonferroni correction

220 for multiple testing $\left(\mathrm{P}<4.6 \times 10^{-4}\right)$. The number of significant $\mathrm{P}$-values obtained in this

221 experiment at the 0.05 alpha level was less than the number of associations expected by chance

222 ( 5). Overall, our negative results do not suggest an association between inflammation-

223 associated SNPs and metabolic traits in Mexican children. This is in line with previous reports

224 from literature, that at best suggest a possible association between inflammation and

225 cardiovascular events(Elliott et al. 2009; Fall et al. 2015; Hingorani 2012; Rafiq et al. 2008;

226 Raman et al. 2013; Varbo et al. 2013; Welsh et al. 2010). Our findings are also supported by the

227 discoveries of hypothesis-free genome-wide association studies for metabolic traits that show a 
228 limited overlap with genetic markers of inflammation to date(Ehret et al. 2011; Locke et al.

229 2015a; Mahajan et al. 2014; Raman et al. 2013; Willer et al. 2013).

230 Power calculations on the standard trait BMI indicate that we only have a fair likelihood to

231 identify associations at the nominal and Bonferroni corrected levels (Supplementary figure 1 and

232 2). Therefore, we cannot totally exclude that the nominal associations reported here are actually

233 true subtle positive results. For instance, we found that the rs7305618 SNP near $H N F 1 A$ was

234 nominally associated with a family history of hypertension. The $H N F 1 A$ gene encodes hepatic

235 nuclear factor 1 alpha (HNF1a), a transcription factor expressed in the liver, pancreas, gut and

236 kidney(Ban et al. 2002). Mutations in the $H N F 1 A$ gene account for approximately $70 \%$ of cases

237 of maturity onset diabetes of the young (MODY)(VaxiHaire et al. 1995). HNF1A mutation

238 carriers display a distinct hypertension status(Owen et al. 2002). HNF-1a is an essential

239 transcription factor in nephron development and rare coding loss-of-function mutations in

240 HNF1A lead to renal malformations and renal dysfunction in mice and humans(Bingham et al.

241 2000; Malecki et al. 2005; Pontoglio et al. 1996). Testing the associations of the HNF1A

242 rs7305618 SNP with adult hypertension in independent studies may therefore be relevant.

243 Similarly, the association of rs1800871 (IL-10) with LDL is indirectly supported by previous

244 reports in literature. While the adenovirus-mediated gene transfer of interleukin-10 in an

245 hyperlipidemic LDLr knock-out mouse model results in lowering of cholesterol levels and 246 attenuation of atherogenesis, interleukin-10 deficiency in a distinct hyperlipidemic 247 apolipoprotein E knock-out mouse model leads to an increase of LDL and 248 atherosclerosis(Caligiuri et al. 2003; Von Der Thusen et al. 2001). However, further studies in 249 independent Mexican children populations are needed to confirm these nominal associations. No 
250 study in children has assessed the association of genetic markers of inflammation with metabolic

251 traits, making any comparisons to our data difficult.

252 Our study has several strengths. It is the first to explore the associations of a representative list of 253 genetic variants related to inflammation with metabolic traits in children and in the Mexican 254 population. Additionally, we assessed diverse metabolic traits including both continuous and 255 binary variables. Limitations of the study include an under-optimal statistical power to identify 256 even substantial genetic effects, especially after corrections for multiple tests (Supplementary 257 Figure 1 and 2). Additionally, the list of SNPs related to inflammation that we assessed did not 258 include the more recent GWAS discoveries for inflammation traits(Raman et al. 2013). We did 259 not assess the association of these SNPs with intermediate inflammatory serum markers (e.g. 260 CRP, sICAM-1, IL-6, soluble P-selectin). Finally, using ancestry informative markers to adjust 261 for potential population stratification was not performed in this study.

262 In conclusion, the association study of 6 SNPs in 5 inflammation-related genes with 10 263 continuous and 8 binary cardio-metabolic traits in 1462 Mexican children does not suggest an association between inflammation-associated SNPs, obesity and its metabolic complications. Additional studies with larger sample sizes, a more exhaustive panel of SNPs and the availability of both inflammatory serum biomarkers and clinical traits in Mexican and other populations will

267 provide a more definitive answer to this important research topic.

\section{Acknowledgements}

269 We acknowledge all the participants of the study. We acknowledge Hudson Reddon and Amel 270 Lamri for their technical assistance.

\section{Supplementary information}


272 Supplementary information is available at the PeerJ website.

273

274

275

276

277

278

279

280

281

282

283

284

285

286

287

288 


\section{References}

290

291

292

293

294

295

296

297

298

299

300

301

302

303

304

305

306

307

308

309

310

311

312

313

314

315

316

317

318

319

320

321

322

323

324

325

326

327

328

329

330

331

332

333

334

Avery $\mathrm{CL}$, He Q, North KE, Ambite JL, Boerwinkle E, Fornage M, Hindorff LA, Kooperberg C, Meigs JB, and Pankow JS. 2011. A phenomics-based strategy identifies loci on APOC1, BRAP, and PLCG1 associated with metabolic syndrome phenotype domains. PLoS genetics 7:e1002322.

Ban N, Yamada Y, Someya Y, Miyawaki K, Ihara Y, Hosokawa M, Toyokuni S, Tsuda K, and Seino Y. 2002. Hepatocyte nuclear factor- $1 \alpha$ recruits the transcriptional co-activator p300 on the GLUT2 gene promoter. Diabetes 51:1409-1418.

Barquera S, Campos-Nonato I, Hernández-Barrera L, Flores M, Durazo-Arvizu R, Kanter R, and Rivera JA. 2009. Obesity and central adiposity in Mexican adults: results from the Mexican National Health and Nutrition Survey 2006. salud publica de mexico 51:S595-S603.

Bingham C, Ellard S, Allen L, Bulman M, Shepherd M, Frayling T, Berry PJ, Clark PM, Lindner T, Bell GI, Ryffel GU, Nicholls AJ, and Hattersley AT. 2000. Abnormal nephron development associated with a frameshift mutation in the transcription factor hepatocyte nuclear factor-1 beta. Kidney Int 57:898-907. 10.1046/j.1523-1755.2000.057003898.x

Brunner EJ, Kivimäki M, Witte DR, Lawlor DA, Smith GD, Cooper JA, Miller M, Lowe GD, Rumley A, and Casas JP. 2008. Inflammation, insulin resistance, and diabetes-Mendelian randomization using CRP haplotypes points upstream. PLoS medicine 5:e155.

Caligiuri G, Rudling M, Ollivier V, Jacob MP, Michel JB, Hansson GK, and Nicoletti A. 2003. Interleukin-10 deficiency increases atherosclerosis, thrombosis, and low-density lipoproteins in apolipoprotein E knockout mice. Mol Med 9:10-17.

Castillo EH, Borges G, Talavera JO, Orozco R, Vargas-Alemán C, Huitrón-Bravo G, Diaz-Montiel JC, Castañón S, and Salmerón J. 2007. Body mass index and the prevalence of metabolic syndrome among children and adolescents in two Mexican populations. Journal of adolescent health 40:521-526.

Consortium I-RMRA. 2012. The interleukin- 6 receptor as a target for prevention of coronary heart disease: a mendelian randomisation analysis. The Lancet 379:1214-1224.

Consortium STD. 2014. Sequence variants in SLC16A11 are a common risk factor for type 2 diabetes in Mexico. Nature 506:97-101.

Ehret GB, Munroe PB, Rice KM, Bochud M, Johnson AD, Chasman DI, Smith AV, Tobin MD, Verwoert GC, Hwang SJ, Pihur V, Vollenweider P, O'Reilly PF, Amin N, Bragg-Gresham JL, Teumer A, Glazer NL, Launer L, Zhao JH, Aulchenko Y, Heath S, Sober S, Parsa A, Luan J, Arora P, Dehghan A, Zhang F, Lucas G, Hicks AA, Jackson AU, Peden JF, Tanaka T, Wild SH, Rudan I, Igl W, Milaneschi Y, Parker AN, Fava C, Chambers JC, Fox ER, Kumari M, Go MJ, van der Harst P, Kao WH, Sjogren M, Vinay DG, Alexander M, Tabara Y, Shaw-Hawkins S, Whincup PH, Liu Y, Shi G, Kuusisto J, Tayo B, Seielstad M, Sim X, Nguyen KD, Lehtimaki T, Matullo G, Wu Y, Gaunt TR, Onland-Moret NC, Cooper MN, Platou CG, Org E, Hardy R, Dahgam S, Palmen J, Vitart V, Braund PS, Kuznetsova T, Uiterwaal CS, Adeyemo A, Palmas W, Campbell H, Ludwig B, Tomaszewski M, Tzoulaki I, Palmer ND, Aspelund T, Garcia M, Chang YP, O'Connell JR, Steinle NI, Grobbee DE, Arking DE, Kardia SL, Morrison AC, Hernandez D, Najjar S, McArdle WL, Hadley D, Brown MJ, Connell JM, Hingorani AD, Day IN, Lawlor DA, Beilby JP, Lawrence RW, Clarke R, Hopewell JC, Ongen H, Dreisbach AW, Li Y, Young JH, Bis JC, Kahonen M, Viikari J, Adair LS, Lee NR, Chen MH, Olden M, Pattaro C, Bolton JA, Kottgen A, Bergmann S, Mooser V, Chaturvedi N, Frayling TM, Islam M, Jafar TH, Erdmann J, Kulkarni SR, Bornstein SR, Grassler J, Groop L, Voight BF, Kettunen J, Howard P, Taylor A, Guarrera S, Ricceri F, Emilsson V, Plump A, Barroso I, Khaw KT, Weder AB, Hunt SC, Sun YV, Bergman RN, Collins FS, Bonnycastle LL, Scott LJ, Stringham HM, Peltonen L, Perola M, Vartiainen E, Brand SM, Staessen JA, Wang TJ, Burton PR, Soler Artigas M, Dong Y, Snieder H, 
Wang X, Zhu H, Lohman KK, Rudock ME, Heckbert SR, Smith NL, Wiggins KL, Doumatey A, Shriner D, Veldre G, Viigimaa M, Kinra S, Prabhakaran D, Tripathy $V$, Langefeld CD, Rosengren $A$, Thelle DS, Corsi AM, Singleton A, Forrester T, Hilton G, McKenzie CA, Salako T, Iwai N, Kita Y, Ogihara $\mathrm{T}$, Ohkubo $\mathrm{T}$, Okamura $\mathrm{T}$, Ueshima $\mathrm{H}$, Umemura $\mathrm{S}$, Eyheramendy $\mathrm{S}$, Meitinger $\mathrm{T}$, Wichmann HE, Cho YS, Kim HL, Lee JY, Scott J, Sehmi JS, Zhang W, Hedblad B, Nilsson P, Smith GD, Wong A, Narisu N, Stancakova A, Raffel LJ, Yao J, Kathiresan S, O'Donnell CJ, Schwartz SM, Ikram MA, Longstreth WT, Jr., Mosley TH, Seshadri S, Shrine NR, Wain LV, Morken MA, Swift AJ, Laitinen J, Prokopenko I, Zitting P, Cooper JA, Humphries SE, Danesh J, Rasheed A, Goel A, Hamsten A, Watkins H, Bakker SJ, van Gilst WH, Janipalli CS, Mani KR, Yajnik CS, Hofman A, Mattace-Raso FU, Oostra BA, Demirkan A, Isaacs A, Rivadeneira F, Lakatta EG, Orru M, Scuteri A, Ala-Korpela M, Kangas AJ, Lyytikainen LP, Soininen $\mathrm{P}$, Tukiainen $\mathrm{T}$, Wurtz $\mathrm{P}$, Ong RT, Dorr $\mathrm{M}$, Kroemer HK, Volker U, Volzke H, Galan P, Hercberg S, Lathrop M, Zelenika D, Deloukas P, Mangino M, Spector TD, Zhai G, Meschia JF, Nalls MA, Sharma P, Terzic J, Kumar MV, Denniff M, Zukowska-Szczechowska E, Wagenknecht LE, Fowkes FG, Charchar FJ, Schwarz PE, Hayward C, Guo X, Rotimi C, Bots ML, Brand E, Samani NJ, Polasek O, Talmud PJ, Nyberg F, Kuh D, Laan M, Hveem K, Palmer L, van der Schouw YT, Casas JP, Mohlke KL, Vineis P, Raitakari O, Ganesh SK, Wong TY, Tai ES, Cooper RS, Laakso M, Rao DC, Harris TB, Morris RW, Dominiczak AF, Kivimaki M, Marmot MG, Miki T, Saleheen D, Chandak GR, Coresh J, Navis G, Salomaa V, Han BG, Zhu X, Kooner JS, Melander O, Ridker PM, Bandinelli S, Gyllensten UB, Wright AF, Wilson JF, Ferrucci L, Farrall M, Tuomilehto J, Pramstaller PP, Elosua R, Soranzo N, Sijbrands EJ, Altshuler D, Loos RJ, Shuldiner AR, Gieger C, Meneton P, Uitterlinden AG, Wareham NJ, Gudnason V, Rotter JI, Rettig $R$, Uda M, Strachan DP, Witteman JC, Hartikainen AL, Beckmann JS, Boerwinkle E, Vasan RS, Boehnke M, Larson MG, Jarvelin MR, Psaty BM, Abecasis GR, Chakravarti A, Elliott P, van Duijn CM, Newton-Cheh C, Levy D, Caulfield MJ, and Johnson T. 2011. Genetic variants in novel pathways influence blood pressure and cardiovascular disease risk. Nature 478:103-109. 10.1038/nature10405

Elks CE, Den Hoed M, Zhao JH, Sharp SJ, Wareham NJ, Loos RJ, and Ong KK. 2012. Variability in the heritability of body mass index: a systematic review and meta-regression. Frontiers in endocrinology 3.

Elliott P, Chambers JC, Zhang W, Clarke R, Hopewell JC, Peden JF, Erdmann J, Braund P, Engert JC, and Bennett D. 2009. Genetic loci associated with C-reactive protein levels and risk of coronary heart disease. JAMA 302:37-48.

Fall T, Hagg S, Ploner A, Magi R, Fischer K, Draisma HH, Sarin AP, Benyamin B, Ladenvall C, Akerlund M, Kals $M$, Esko T, Nelson CP, Kaakinen M, Huikari V, Mangino M, Meirhaeghe A, Kristiansson $K$, Nuotio ML, Kobl M, Grallert H, Dehghan A, Kuningas M, de Vries PS, de Bruijn RF, Willems SM, Heikkila K, Silventoinen K, Pietilainen KH, Legry V, Giedraitis V, Goumidi L, Syvanen AC, Strauch K, Koenig W, Lichtner P, Herder C, Palotie A, Menni C, Uitterlinden AG, Kuulasmaa K, Havulinna AS, Moreno LA, Gonzalez-Gross M, Evans A, Tregouet DA, Yarnell JW, Virtamo J, Ferrieres J, Veronesi G, Perola M, Arveiler D, Brambilla P, Lind L, Kaprio J, Hofman A, Stricker BH, van Duijn CM, Ikram MA, Franco OH, Cottel D, Dallongeville J, Hall AS, Jula A, Tobin MD, Penninx BW, Peters A, Gieger C, Samani NJ, Montgomery GW, Whitfield JB, Martin NG, Groop L, Spector TD, Magnusson PK, Amouyel P, Boomsma DI, Nilsson PM, Jarvelin MR, Lyssenko V, Metspalu A, Strachan DP, Salomaa V, Ripatti S, Pedersen NL, Prokopenko I, McCarthy MI, and Ingelsson E. 2015. Age- and Sex-Specific Causal Effects of Adiposity on Cardiovascular Risk Factors. Diabetes. $10.2337 / \mathrm{db} 14-0988$

Hingorani AD, Casas, J.P. 2012. Interleukin-6 Receptor Mendelian Randomisation Analysis (IL6R MR) Consortium The interleukin- 6 receptor as a target for prevention of coronary heart disease: $A$ mendelian randomisation analysis. Lancet 379:1214-1224. 
383

Hossain P, Kawar B, and El Nahas M. 2007. Obesity and diabetes in the developing world-a growing challenge. New England Journal of Medicine 356:213-215.

Hotamisligil GS. 2006. Inflammation and metabolic disorders. Nature 444:860-867.

Isordia-Salas I, Santiago-Germán D, Rodrìguez-Navarro H, Almaráz-Delgado M, Leaños-Miranda A, Anaya-Gómez F, Borrayo-Sánchez G, and Majluf-Cruz A. 2011. Prevalence of metabolic syndrome components in an urban Mexican sample: comparison between two classifications. Experimental Diabetes Research 2012.

Kalra S, Gandhi A, Kalra B, and Agrawal N. 2009. Management of dyslipidemia in children. Diabetol Metab Syndr 1:26. 10.1186/1758-5996-1-26

Karelis A, Brochu M, and Rabasa-Lhoret R. 2004. Can we identify metabolically healthy but obese individuals (MHO)? Diabetes \& metabolism 30:569-572.

Kilpelainen TO, Laaksonen DE, Lakka TA, Herder C, Koenig W, Lindstrom J, Eriksson JG, Uusitupa M, Kolb H, Laakso M, and Tuomilehto J. 2010. The rs1800629 polymorphism in the TNF gene interacts with physical activity on the changes in C-reactive protein levels in the Finnish Diabetes Prevention Study. Exp Clin Endocrinol Diabetes 118:757-759. 10.1055/s-0030-1249686

Kramer CK, Zinman B, and Retnakaran R. 2013. Are metabolically healthy overweight and obesity benign conditions?: A systematic review and meta-analysis. Annals of internal medicine 159:758-769.

León-Mimila $\mathrm{P}$, Villamil-Ramírez $\mathrm{H}$, Villalobos-Comparán $\mathrm{M}$, Villarreal-Molina $\mathrm{T}$, Romero-Hidalgo $\mathrm{S}$, López-Contreras B, Gutiérrez-Vidal R, Vega-Badillo J, Jacobo-Albavera L, and Posadas-Romeros C. 2013. Contribution of common genetic variants to obesity and obesity-related traits in mexican children and adults. Plos one 8:e70640.

Lisker R, Ramirez E, and Babinsky V. 1996. Genetic structure of autochthonous populations of MesoAmerica: Mexico. Human Biology:395-404.

Lisker RR, E.; Babinsky, V.; 1996. Genetic structure of autochthonous populations of Meso-America: Mexico. Human Biology 68:395-404.

Locke AE, Kahali B, Berndt SI, Justice AE, Pers TH, Day FR, Powell C, Vedantam S, Buchkovich ML, and Yang J. 2015a. Genetic studies of body mass index yield new insights for obesity biology. Nature 518:197-206.

Locke AE, Kahali B, Berndt SI, Justice AE, Pers TH, Day FR, Powell C, Vedantam S, Buchkovich ML, Yang J, Croteau-Chonka DC, Esko T, Fall T, Ferreira T, Gustafsson S, Kutalik Z, Luan J, Magi R, Randall JC, Winkler TW, Wood AR, Workalemahu T, Faul JD, Smith JA, Hua Zhao J, Zhao W, Chen J, Fehrmann R, Hedman AK, Karjalainen J, Schmidt EM, Absher D, Amin N, Anderson D, Beekman M, Bolton JL, Bragg-Gresham JL, Buyske S, Demirkan A, Deng G, Ehret GB, Feenstra B, Feitosa MF, Fischer K, Goel A, Gong J, Jackson AU, Kanoni S, Kleber ME, Kristiansson K, Lim U, Lotay V, Mangino M, Mateo Leach I, Medina-Gomez C, Medland SE, Nalls MA, Palmer CD, Pasko D, Pechlivanis S, Peters MJ, Prokopenko I, Shungin D, Stancakova A, Strawbridge RJ, Ju Sung Y, Tanaka T, Teumer A, Trompet S, van der Laan SW, van Setten J, Van Vliet-Ostaptchouk JV, Wang Z, Yengo L, Zhang W, Isaacs A, Albrecht E, Arnlov J, Arscott GM, Attwood AP, Bandinelli S, Barrett A, Bas IN, Bellis C, Bennett AJ, Berne C, Blagieva R, Bluher M, Bohringer S, Bonnycastle LL, Bottcher Y, Boyd HA, Bruinenberg M, Caspersen IH, Ida Chen YD, Clarke R, Daw EW, de Craen AJ, Delgado G, Dimitriou M, Doney AS, Eklund N, Estrada K, Eury E, Folkersen L, Fraser RM, Garcia ME, Geller F, Giedraitis V, Gigante B, Go AS, Golay A, Goodall AH, Gordon SD, Gorski M, Grabe HJ, Grallert H, Grammer TB, Grassler J, Gronberg H, Groves CJ, Gusto G, Haessler J, Hall P, Haller T, Hallmans G, Hartman CA, Hassinen M, Hayward C, Heard-Costa NL, Helmer Q, Hengstenberg C, Holmen O, Hottenga JJ, James AL, Jeff JM, Johansson A, Jolley J, Juliusdottir T, Kinnunen L, Koenig W, Koskenvuo M, Kratzer W, Laitinen J, Lamina C, Leander K, Lee NR, Lichtner P, Lind L, Lindstrom J, Sin Lo K, Lobbens S, Lorbeer R, Lu Y, Mach F, Magnusson PK, Mahajan A, McArdle WL, McLachlan S, Menni C, Merger S, Mihailov E, Milani L, Moayyeri A, Monda KL, Morken MA, 
431

432

433

434

435

436

437

438

439

440

441

442

443

444

445

446

447

448

449

450

451

452

453

454

455

456

457

458

459

460

461

462

463

464

465

466

467

468

469

470

471

472

473

474

475

476

477

478

Mulas A, Muller G, Muller-Nurasyid M, Musk AW, Nagaraja R, Nothen MM, Nolte IM, Pilz S, Rayner NW, Renstrom F, Rettig R, Ried JS, Ripke S, Robertson NR, Rose LM, Sanna S, Scharnagl H, Scholtens S, Schumacher FR, Scott WR, Seufferlein T, Shi J, Vernon Smith A, Smolonska J, Stanton AV, Steinthorsdottir V, Stirrups K, Stringham HM, Sundstrom J, Swertz MA, Swift AJ, Syvanen AC, Tan ST, Tayo BO, Thorand B, Thorleifsson G, Tyrer JP, Uh HW, Vandenput L, Verhulst FC, Vermeulen SH, Verweij N, Vonk JM, Waite LL, Warren HR, Waterworth D, Weedon MN, Wilkens LR, Willenborg C, Wilsgaard T, Wojczynski MK, Wong A, Wright AF, Zhang Q, Brennan EP, Choi M, Dastani Z, Drong AW, Eriksson P, Franco-Cereceda A, Gadin JR, Gharavi AG, Goddard ME, Handsaker RE, Huang J, Karpe F, Kathiresan S, Keildson S, Kiryluk K, Kubo M, Lee JY, Liang L, Lifton RP, Ma B, McCarroll SA, McKnight AJ, Min JL, Moffatt MF, Montgomery GW, Murabito JM, Nicholson G, Nyholt DR, Okada Y, Perry JR, Dorajoo R, Reinmaa E, Salem RM, Sandholm N, Scott RA, Stolk L, Takahashi A, Van't Hooft FM, Vinkhuyzen AA, Westra HJ, Zheng W, Zondervan KT, Heath AC, Arveiler D, Bakker SJ, Beilby J, Bergman RN, Blangero J, Bovet P, Campbell H, Caulfield MJ, Cesana G, Chakravarti A, Chasman DI, Chines PS, Collins FS, Crawford DC, Cupples LA, Cusi D, Danesh J, de Faire U, den Ruijter HM, Dominiczak AF, Erbel R, Erdmann J, Eriksson JG, Farrall M, Felix SB, Ferrannini E, Ferrieres J, Ford I, Forouhi NG, Forrester T, Franco OH, Gansevoort RT, Gejman PV, Gieger C, Gottesman O, Gudnason V, Gyllensten U, Hall AS, Harris TB, Hattersley AT, Hicks AA, Hindorff LA, Hingorani AD, Hofman A, Homuth G, Hovingh GK, Humphries SE, Hunt SC, Hypponen E, Illig T, Jacobs KB, Jarvelin MR, Jockel KH, Johansen B, Jousilahti $P$, Jukema JW, Jula AM, Kaprio J, Kastelein JJ, Keinanen-Kiukaanniemi SM, Kiemeney LA, Knekt P, Kooner JS, Kooperberg C, Kovacs P, Kraja AT, Kumari M, Kuusisto J, Lakka TA, Langenberg C, Le Marchand L, Lehtimaki T, Lyssenko V, Mannisto S, Marette A, Matise TC, McKenzie CA, McKnight B, Moll FL, Morris AD, Morris AP, Murray JC, Nelis M, Ohlsson C, Oldehinkel AJ, Ong KK, Madden PA, Pasterkamp G, Peden JF, Peters A, Postma DS, Pramstaller PP, Price JF, Qi L, Raitakari OT, Rankinen T, Rao DC, Rice TK, Ridker PM, Rioux JD, Ritchie MD, Rudan I, Salomaa V, Samani NJ, Saramies J, Sarzynski MA, Schunkert H, Schwarz PE, Sever P, Shuldiner AR, Sinisalo J, Stolk RP, Strauch K, Tonjes A, Tregouet DA, Tremblay A, Tremoli E, Virtamo J, Vohl MC, Volker U, Waeber G, Willemsen G, Witteman JC, Zillikens MC, Adair LS, Amouyel P, Asselbergs FW, Assimes TL, Bochud M, Boehm BO, Boerwinkle E, Bornstein SR, Bottinger EP, Bouchard C, Cauchi S, Chambers JC, Chanock SJ, Cooper RS, de Bakker PI, Dedoussis G, Ferrucci L, Franks PW, Froguel P, Groop LC, Haiman CA, Hamsten A, Hui J, Hunter DJ, Hveem K, Kaplan RC, Kivimaki M, Kuh D, Laakso M, Liu Y, Martin NG, Marz W, Melbye M, Metspalu A, Moebus S, Munroe PB, Njolstad I, Oostra BA, Palmer CN, Pedersen NL, Perola M, Perusse L, Peters U, Power C, Quertermous T, Rauramaa R, Rivadeneira F, Saaristo TE, Saleheen D, Sattar N, Schadt EE, Schlessinger D, Slagboom PE, Snieder H, Spector TD, Thorsteinsdottir U, Stumvoll $M$, Tuomilehto J, Uitterlinden AG, Uusitupa $M$, van der Harst $P$, Walker $M$, Wallaschofski $\mathrm{H}$, Wareham NJ, Watkins $\mathrm{H}$, Weir DR, Wichmann HE, Wilson JF, Zanen P, Borecki IB, Deloukas P, Fox CS, Heid IM, O'Connell JR, Strachan DP, Stefansson K, van Duijn CM, Abecasis GR, Franke L, Frayling TM, McCarthy MI, Visscher PM, Scherag A, Willer CJ, Boehnke M, Mohlke $\mathrm{KL}$, Lindgren CM, Beckmann JS, Barroso I, North KE, Ingelsson E, Hirschhorn JN, Loos RJ, and Speliotes EK. 2015b. Genetic studies of body mass index yield new insights for obesity biology. Nature 518:197-206. 10.1038/nature14177

Mahajan A, Go MJ, Zhang W, Below JE, Gaulton KJ, Ferreira T, Horikoshi M, Johnson AD, Ng MC, Prokopenko I, Saleheen D, Wang X, Zeggini E, Abecasis GR, Adair LS, Almgren P, Atalay M, Aung T, Baldassarre D, Balkau B, Bao Y, Barnett AH, Barroso I, Basit A, Been LF, Beilby J, Bell GI, Benediktsson R, Bergman RN, Boehm BO, Boerwinkle E, Bonnycastle LL, Burtt N, Cai Q, Campbell H, Carey J, Cauchi S, Caulfield M, Chan JC, Chang LC, Chang TJ, Chang YC, Charpentier G, Chen $\mathrm{CH}$, Chen H, Chen YT, Chia KS, Chidambaram M, Chines PS, Cho NH, Cho YM, Chuang LM, Collins 
FS, Cornelis MC, Couper DJ, Crenshaw AT, van Dam RM, Danesh J, Das D, de Faire U, Dedoussis G, Deloukas P, Dimas AS, Dina C, Doney AS, Donnelly PJ, Dorkhan M, van Duijn C, Dupuis J, Edkins S, Elliott P, Emilsson V, Erbel R, Eriksson JG, Escobedo J, Esko T, Eury E, Florez JC, Fontanillas $P$, Forouhi NG, Forsen T, Fox C, Fraser RM, Frayling TM, Froguel P, Frossard P, Gao Y, Gertow K, Gieger C, Gigante B, Grallert H, Grant GB, Grrop LC, Groves CJ, Grundberg E, Guiducci C, Hamsten A, Han BG, Hara K, Hassanali N, Hattersley AT, Hayward C, Hedman AK, Herder C, Hofman A, Holmen OL, Hovingh K, Hreidarsson AB, Hu C, Hu FB, Hui J, Humphries SE, Hunt SE, Hunter DJ, Hveem K, Hydrie ZI, Ikegami H, Illig T, Ingelsson E, Islam M, Isomaa B, Jackson AU, Jafar T, James A, Jia W, Jockel KH, Jonsson A, Jowett JB, Kadowaki T, Kang HM, Kanoni S, Kao WH, Kathiresan S, Kato N, Katulanda P, Keinanen-Kiukaanniemi KM, Kelly AM, Khan H, Khaw KT, Khor CC, Kim HL, Kim S, Kim YJ, Kinnunen L, Klopp N, Kong A, Korpi-Hyovalti E, Kowlessur S, Kraft P, Kravic J, Kristensen MM, Krithika S, Kumar A, Kumate J, Kuusisto J, Kwak SH, Laakso M, Lagou V, Lakka TA, Langenberg C, Langford C, Lawrence R, Leander K, Lee JM, Lee NR, Li M, Li X, Li Y, Liang J, Liju S, Lim WY, Lind L, Lindgren CM, Lindholm E, Liu CT, Liu JJ, Lobbens S, Long J, Loos RJ, Lu W, Luan J, Lyssenko V, Ma RC, Maeda S, Magi R, Mannisto S, Matthews DR, Meigs JB, Melander O, Metspalu A, Meyer J, Mirza G, Mihailov E, Moebus S, Mohan V, Mohlke KL, Morris AD, Muhleisen TW, Muller-Nurasyid M, Musk B, Nakamura J, Nakashima E, Navarro P, Ng PK, Nica AC, Nilsson PM, Njolstad I, Nothen MM, Ohnaka K, Ong TH, Owen KR, Palmer CN, Pankow JS, Park KS, Parkin M, Pechlivanis S, Pedersen NL, Peltonen L, Perry JR, Peters A, Pinidiyapathirage JM, Platou CG, Potter S, Price JF, Qi L, Radha V, Rallidis L, Rasheed A, Rathman W, Rauramaa R, Raychaudhuri S, Rayner NW, Rees SD, Rehnberg E, Ripatti S, Robertson N, Roden M, Rossin EJ, Rudan I, Rybin D, Saaristo TE, Salomaa V, Saltevo J, Samuel M, Sanghera DK, Saramies J, Scott J, Scott L, Scott RA, Segre AV, Sehmi J, Sennblad B, Shah N, Shah S, Shera AS, Shu XO, Shuldiner AR, Sigurdsson G, Sijbrands E, Silveira A, Sim X, Sivapalaratnam S, Small KS, So WY, Stancakova A, Stefansson K, Steinbach G, Steinthorsdottir V, Stirrups K, Strawbridge RJ, Stringham HM, Sun Q, Suo C, Syvanen AC, Takayanagi R, Takeuchi F, Tay WT, Teslovich TM, Thorand B, Thorleifsson G, Thorsteinsdottir U, Tikkanen E, Trakalo J, Tremoli E, Trip MD, Tsai FJ, Tuomi T, Tuomilehto J, Uitterlinden AG, Valladares-Salgado A, Vedantam S, Veglia F, Voight BF, Wang C, Wareham NJ, Wennauer R, Wickremasinghe AR, Wilsgaard T, Wilson JF, Wiltshire S, Winckler W, Wong TY, Wood AR, Wu JY, Wu Y, Yamamoto K, Yamauchi T, Yang M, Yengo L, Yokota M, Young R, Zabaneh D, Zhang F, Zhang R, Zheng W, Zimmet PZ, Altshuler D, Bowden DW, Cho YS, Cox NJ, Cruz M, Hanis CL, Kooner J, Lee JY, Seielstad M, Teo YY, Boehnke M, Parra EJ, Chambers JC, Tai ES, McCarthy MI, and Morris AP. 2014. Genome-wide trans-ancestry metaanalysis provides insight into the genetic architecture of type 2 diabetes susceptibility. Nat Genet 46:234-244. 10.1038/ng.2897

Malecki MT, Skupien J, Gorczynska-Kosiorz S, Klupa T, Nazim J, Moczulski DK, and Sieradzki J. 2005. Renal malformations may be linked to mutations in the hepatocyte nuclear factor-1alpha (MODY3) gene. Diabetes Care 28:2774-2776.

Norden-Krichmar TM, Gizer IR, Libiger O, Wilhelmsen KC, Ehlers CL, and Schork NJ. 2014. Correlation analysis of genetic admixture and social identification with body mass index in a Native American community. American Journal of Human Biology 26:347-360.

Ogden CL, Carroll MD, Curtin LR, Lamb MM, and Flegal KM. 2010. Prevalence of high body mass index in US children and adolescents, 2007-2008. JAMA 303:242-249.

Ogden CL, Carroll MD, Kit BK, and Flegal KM. 2014. Prevalence of childhood and adult obesity in the United States, 2011-2012. JAMA 311:806-814.

Ortega L, Navarro P, Riestra P, Gavela-Perez T, Soriano-Guillen L, and Garces C. 2014. Association of resistin polymorphisms with resistin levels and lipid profile in children. Mol Biol Rep 41:76597664. 10.1007/s11033-014-3658-8 
527
Owen KR, Shepherd M, Stride A, Ellard S, and Hattersley AT. 2002. Heterogeneity in young adult onset diabetes: aetiology alters clinical characteristics. Diabet Med 19:758-761.

Pontoglio M, Barra J, Hadchouel M, Doyen A, Kress C, Bach JP, Babinet C, and Yaniv M. 1996. Hepatocyte nuclear factor 1 inactivation results in hepatic dysfunction, phenylketonuria, and renal Fanconi syndrome. Cell 84:575-585.

Rafiq S, Melzer D, Weedon M, Lango H, Saxena R, Scott L, Palmer C, Morris A, McCarthy M, and Ferrucci L. 2008. Gene variants influencing measures of inflammation or predisposing to autoimmune and inflammatory diseases are not associated with the risk of type 2 diabetes. Diabetologia 51:2205-2213.

Raman K, Chong M, Akhtar-Danesh G-G, D'Mello M, Hasso R, Ross S, Xu F, and Paré G. 2013. Genetic markers of inflammation and their role in cardiovascular disease. Canadian Journal of Cardiology 29:67-74.

Rivera JA, Barquera S, Campirano F, Campos I, Safdie M, and Tovar V. 2002. Epidemiological and nutritional transition in Mexico: rapid increase of non-communicable chronic diseases and obesity. Public health nutrition 5:113-122.

Tounian P, Aggoun Y, Dubern B, Varille V, Guy-Grand B, Sidi D, Girardet J-P, and Bonnet D. 2001. Presence of increased stiffness of the common carotid artery and endothelial dysfunction in severely obese children: a prospective study. The Lancet 358:1400-1404.

van Vliet-Ostaptchouk J, den Hoed M, Luan J, Zhao J, Ong K, Van Der Most P, Wong A, Hardy R, Kuh D, and van der Klauw M. 2013. Pleiotropic effects of obesity-susceptibility loci on metabolic traits: a meta-analysis of up to 37,874 individuals. Diabetologia 56:2134-2146.

Varbo A, Benn M, Tybjærg-Hansen A, and Nordestgaard BG. 2013. Elevated remnant cholesterol causes both low-grade inflammation and ischemic heart disease, whereas elevated low-density lipoprotein cholesterol causes ischemic heart disease without inflammation. Circulation 128:1298-1309.

Vattikuti S, Guo J, and Chow CC. 2012. Heritability and genetic correlations explained by common SNPs for metabolic syndrome traits. PLoS genetics 8:e1002637.

VaxiHaire M, Valérie Boccio AP, Vigouroux C, Terwilliger J, Passa P, Beckmann JS, and Velho G. 1995. A gene for maturity onset diabetes of the young (MODY) maps to chromosome 12q. Nature Genet 9:418-423.

Von Der Thusen JH, Kuiper J, Fekkes ML, De Vos P, Van Berkel TJ, and Biessen EA. 2001. Attenuation of atherogenesis by systemic and local adenovirus-mediated gene transfer of interleukin-10 in LDLr-/- mice. FASEB J 15:2730-2732. 10.1096/fj.01-0483fje

Walker S, Gurka M, Oliver M, Johns D, and DeBoer M. 2012. Racial/ethnic discrepancies in the metabolic syndrome begin in childhood and persist after adjustment for environmental factors. Nutrition, Metabolism and Cardiovascular Diseases 22:141-148.

Wang AH, Lam WJ, Han DY, Ding Y, Hu R, Fraser AG, Ferguson LR, and Morgan AR. 2011. The effect of IL10 genetic variation and interleukin 10 serum levels on Crohn's disease susceptibility in a New Zealand population. Hum Immunol 72:431-435. 10.1016/j.humimm.2011.02.014

Weiss R, Bremer AA, and Lustig RH. 2013. What is metabolic syndrome, and why are children getting it? Annals of the New York Academy of Sciences 1281:123-140.

Wellen KE, and Hotamisligil GS. 2005. Inflammation, stress, and diabetes. Journal of Clinical Investigation 115:1111.

Welsh P, Polisecki E, Robertson M, Jahn S, Buckley BM, de Craen AJ, Ford I, Jukema JW, Macfarlane PW, and Packard CJ. 2010. Unraveling the directional link between adiposity and inflammation: a bidirectional Mendelian randomization approach. The Journal of Clinical Endocrinology \& Metabolism 95:93-99. 
574

575

576

577

578

579

580

581

582

583

584

585

586

587

588

589

590

591

592

593

594

595

596

597

598

599

600

601

602

603

604

605

606

607

608

609

610

611

612

613

614
Willer CJ, Schmidt EM, Sengupta S, Peloso GM, Gustafsson S, Kanoni S, Ganna A, Chen J, Buchkovich ML, Mora S, Beckmann JS, Bragg-Gresham JL, Chang HY, Demirkan A, Den Hertog HM, Do R, Donnelly LA, Ehret GB, Esko T, Feitosa MF, Ferreira T, Fischer K, Fontanillas P, Fraser RM, Freitag DF, Gurdasani D, Heikkila K, Hypponen E, Isaacs A, Jackson AU, Johansson A, Johnson T, Kaakinen $M$, Kettunen J, Kleber ME, Li X, Luan J, Lyytikainen LP, Magnusson PK, Mangino M, Mihailov E, Montasser ME, Muller-Nurasyid M, Nolte IM, O'Connell JR, Palmer CD, Perola M, Petersen AK, Sanna S, Saxena R, Service SK, Shah S, Shungin D, Sidore C, Song C, Strawbridge RJ, Surakka I, Tanaka T, Teslovich TM, Thorleifsson G, Van den Herik EG, Voight BF, Volcik KA, Waite LL, Wong A, Wu Y, Zhang W, Absher D, Asiki G, Barroso I, Been LF, Bolton JL, Bonnycastle LL, Brambilla P, Burnett MS, Cesana G, Dimitriou M, Doney AS, Doring A, Elliott P, Epstein SE, Eyjolfsson GI, Gigante B, Goodarzi MO, Grallert H, Gravito ML, Groves CJ, Hallmans G, Hartikainen AL, Hayward C, Hernandez D, Hicks AA, Holm H, Hung YJ, Illig T, Jones MR, Kaleebu P, Kastelein JJ, Khaw KT, Kim E, Klopp N, Komulainen P, Kumari M, Langenberg C, Lehtimaki T, Lin SY, Lindstrom J, Loos RJ, Mach F, McArdle WL, Meisinger C, Mitchell BD, Muller G, Nagaraja R, Narisu N, Nieminen TV, Nsubuga RN, Olafsson I, Ong KK, Palotie A, Papamarkou T, Pomilla C, Pouta A, Rader DJ, Reilly MP, Ridker PM, Rivadeneira F, Rudan I, Ruokonen A, Samani N, Scharnagl H, Seeley J, Silander K, Stancakova A, Stirrups K, Swift AJ, Tiret L, Uitterlinden AG, van Pelt LJ, Vedantam S, Wainwright $\mathrm{N}$, Wijmenga C, Wild SH, Willemsen G, Wilsgaard T, Wilson JF, Young EH, Zhao JH, Adair LS, Arveiler D, Assimes TL, Bandinelli S, Bennett F, Bochud M, Boehm BO, Boomsma DI, Borecki IB, Bornstein SR, Bovet P, Burnier M, Campbell H, Chakravarti A, Chambers JC, Chen YD, Collins FS, Cooper RS, Danesh J, Dedoussis G, de Faire U, Feranil AB, Ferrieres J, Ferrucci L, Freimer NB, Gieger C, Groop LC, Gudnason V, Gyllensten U, Hamsten A, Harris TB, Hingorani A, Hirschhorn JN, Hofman A, Hovingh GK, Hsiung CA, Humphries SE, Hunt SC, Hveem K, Iribarren C, Jarvelin MR, Jula A, Kahonen M, Kaprio J, Kesaniemi A, Kivimaki M, Kooner JS, Koudstaal PJ, Krauss RM, Kuh D, Kuusisto J, Kyvik KO, Laakso M, Lakka TA, Lind L, Lindgren CM, Martin NG, Marz W, McCarthy MI, McKenzie CA, Meneton P, Metspalu A, Moilanen L, Morris AD, Munroe PB, Njolstad I, Pedersen NL, Power C, Pramstaller PP, Price JF, Psaty BM, Quertermous T, Rauramaa R, Saleheen D, Salomaa V, Sanghera DK, Saramies J, Schwarz PE, Sheu WH, Shuldiner AR, Siegbahn A, Spector TD, Stefansson K, Strachan DP, Tayo BO, Tremoli E, Tuomilehto J, Uusitupa $M$, van Duijn CM, Vollenweider P, Wallentin L, Wareham NJ, Whitfield JB, Wolffenbuttel BH, Ordovas JM, Boerwinkle E, Palmer CN, Thorsteinsdottir U, Chasman DI, Rotter JI, Franks PW, Ripatti S, Cupples LA, Sandhu MS, Rich SS, Boehnke M, Deloukas P, Kathiresan S, Mohlke KL, Ingelsson E, and Abecasis GR. 2013. Discovery and refinement of loci associated with lipid levels. Nat Genet 45:1274-1283. 10.1038/ng.2797

Yazdi FT, Clee SM, and Meyre D. 2015. Obesity genetics in mouse and human: back and forth, and back again. PeerJ 3:e856. 10.7717/peerj.856 
615 Table 1. Characteristics of the Mexican children population.

\begin{tabular}{|l|c|c|}
\hline \multicolumn{1}{|c|}{ Trait } & $\begin{array}{c}\text { Mean } \pm \\
\text { Standard } \\
\text { Deviation }\end{array}$ & Sample Size \\
\hline Sex (\% Male/Female) & $53.0 / 47.0$ & $775 / 687$ \\
\hline Age (Years) & $9.24 \pm 2.07$ & 1462 \\
\hline BMI (Kg/m2) & $19.65 \pm 4.20$ & 1461 \\
\hline Waist to hip ratio & $0.85 \pm 0.06$ & 1417 \\
\hline Systolic blood pressure (mmHg) & $98.58 \pm 10.88$ & 1457 \\
\hline Diastolic blood pressure (mmHg) & $66.25 \pm 8.80$ & 1458 \\
\hline & $102.43 \pm 26.43$ & 1462 \\
\hline Low density lipoprotein-cholesterol (mg/dl) & $50.58 \pm 12.82$ & 1462 \\
\hline High density lipoprotein-cholesterol (mg/dl) & $157.27 \pm 33.53$ & 1462 \\
\hline & & 1462 \\
\hline Total cholesterol (mg/dl) & $93.67 \pm 49.69$ & 1461 \\
\hline Triglycerides (mg/dl) & $4.57 \pm 0.53$ & 1148 \\
\hline Fasting glucose (mmol/l) & $9.10 \pm 7.05$ & 1462 \\
\hline Fasting insulin (mIU/l) & 1.40 & 1462 \\
\hline Underweight (\%) & 49.40 & 1462 \\
\hline Normal weight (\%) & 21.30 & 1462 \\
\hline Overweight (\%) & 27.90 & 1452 \\
\hline Obese (\%) & 1.50 & 1456 \\
\hline Hypertension (\%) & 3.10 & 1461 \\
\hline Hyperglycemia (\%) & 34.90 & 11.98 \\
\hline Dyslipidemia (\%) & 16.29 & \\
\hline Type 2 diabetes family history (\%) & 53.05 & \\
\hline Hypertension family history (\%) & & \\
\hline Overweight / obesity family history (\%) & \\
\hline
\end{tabular}


Table 2. Association between 6 genetic markers of inflammation and 10 continuous metabolic traits.

\begin{tabular}{|c|c|c|c|c|c|c|c|c|c|c|}
\hline & $\mathbf{B M I}^{\mathbf{a}}$ & WHR $^{\mathbf{a}}$ & SBPa $^{a}$ & DBPa $^{a}$ & LDL & HDL & $\mathbf{T C}^{\mathbf{a}}$ & $\mathbf{T G}^{\mathbf{a}}$ & FG & $\mathbf{F} \mathbf{I}^{\mathbf{a}}$ \\
\hline $\begin{array}{l}\text { rs1137101 } \\
(L E P R)\end{array}$ & $\begin{array}{l}0.002 \\
0.007 \\
(0.83) \\
\end{array}$ & $\begin{array}{ll}-0.003 \quad \pm \\
0.002 \\
(0.19) & \\
\end{array}$ & $\begin{array}{ll}-0.001 & \pm \\
0.004 & \\
(0.83) & \\
\end{array}$ & $\begin{array}{l}0.003 \\
0.005 \\
(0.50) \\
\end{array}$ & $\begin{array}{ll}-0.023 \quad \pm \\
0.980 & \\
(0.38) & \\
\end{array}$ & $\begin{array}{l}-0.009 \\
0.477 \\
(0.73) \\
\end{array}$ & $\begin{array}{ll}-0.008 \quad \pm \\
0.007 \\
(0.27)\end{array}$ & $\begin{array}{ll}-0.007 \quad \pm \\
0.017 & \\
(0.66) & \\
\end{array}$ & $\begin{array}{ll}-0.019 \quad \pm \\
0.020 \\
(0.47) & \\
\end{array}$ & $\begin{array}{ll}-0.008 \quad \pm \\
0.026 & \\
(0.78) & \\
\end{array}$ \\
\hline $\begin{array}{l}\text { rs7305618 } \\
(H N F 1 A)\end{array}$ & $\begin{array}{l}-0.003 \\
0.010 \\
(0.76)\end{array}$ & $\begin{array}{l}-0.004 \quad \pm \\
0.004 \\
(0.319)\end{array}$ & $\begin{array}{l}-0.006 \\
0.006 \\
(0.31)\end{array}$ & $\begin{array}{l}-0.010 \\
0.007 \\
(0.15)\end{array}$ & $\begin{array}{l}0.011 \\
1.478 \\
(0.69)\end{array}$ & $\begin{array}{l}0.006 \\
0.717 \\
(0.83)\end{array}$ & $\begin{array}{l}-0.006 \\
0.011 \\
(0.57)\end{array}$ & $\begin{array}{l}-0.016 \quad \pm \\
0.025 \\
(0.53)\end{array}$ & $\begin{array}{l}0.010 \\
0.029 \\
(0.71)\end{array}$ & $\begin{array}{l}0.029 \quad \pm \\
0.040 \\
(0.46)\end{array}$ \\
\hline $\begin{array}{l}\text { rs1800629 } \\
(T N F A)^{b}\end{array}$ & $\begin{array}{l}0.002 \\
0.017 \\
(0.93)\end{array}$ & $\begin{array}{l}0.008 \\
0.006 \\
(0.75)\end{array}$ & $\begin{array}{l}0.022 \\
0.010 \\
(0.37)\end{array}$ & $\begin{array}{l}0.005 \\
0.012 \\
(0.85)\end{array}$ & $\begin{array}{l}0.002 \\
2.394 \\
(0.93)\end{array}$ & $\begin{array}{l}0.037 \\
1.156 \\
(0.14)\end{array}$ & $\begin{array}{l}0.006 \\
0.019 \\
(0.81)\end{array}$ & $\begin{array}{l}0.021 \\
0.043 \\
(0.42)\end{array}$ & $\begin{array}{l}0.031 \\
4.619 \\
(0.24)\end{array}$ & $\begin{array}{l}0.000 \quad \pm \\
0.066 \\
(0.99)\end{array}$ \\
\hline $\begin{array}{l}\text { rs1800896 } \\
(I L-10)\end{array}$ & $\begin{array}{l}-0.001 \\
0.008 \\
(0.94)\end{array}$ & $\begin{array}{l}-0.003 \\
0.003 \\
(0.38)\end{array}$ & $\begin{array}{l}0.005 \\
0.004 \\
(0.28)\end{array}$ & $\begin{array}{l}0.004 \\
0.006 \\
(0.53)\end{array}$ & $\begin{array}{l}-0.006 \\
1.158 \\
(0.84)\end{array}$ & $\begin{array}{l}0.012 \\
0.566 \\
(0.65)\end{array}$ & $\begin{array}{l}-0.001 \quad \pm \\
0.009 \\
(0.92)\end{array}$ & $\begin{array}{l}-0.018 \quad \pm \\
0.020 \\
(0.37)\end{array}$ & $\begin{array}{l}0.034 \\
0.023 \\
(0.21)\end{array}$ & $\begin{array}{l}3.89 \times 10^{-5} \pm \\
0.031 \\
(0.99)\end{array}$ \\
\hline $\begin{array}{l}\text { rs1800871 } \\
(I L-10)\end{array}$ & $\begin{array}{l}-0.005 \\
0.007 \\
(0.49)\end{array}$ & $\begin{array}{l}-0.001 \\
0.003 \\
(0.57)\end{array}$ & $\begin{array}{l}-0.004 \\
0.004 \\
(0.33)\end{array}$ & $\begin{array}{l}-0.005 \\
0.005 \\
(0.31)\end{array}$ & $\begin{array}{l}-0.068 \\
1.006 \\
(0.01)\end{array}$ & $\begin{array}{l}-0.011 \\
0.489 \\
(0.67)\end{array}$ & $\begin{array}{l}-0.010 \quad \pm \\
0.008 \\
(0.19)\end{array}$ & $\begin{array}{l}0.010 \quad \pm \\
0.017 \\
(0.56)\end{array}$ & $\begin{array}{l}-0.006 \quad \pm \\
0.020 \\
(0.82)\end{array}$ & $\begin{array}{l}-0.024 \quad \pm \\
0.027 \\
(0.37)\end{array}$ \\
\hline $\begin{array}{l}\text { rs1862513 } \\
(R E T N)\end{array}$ & $\begin{array}{l}-0.020 \\
0.011 \\
(0.08)\end{array}$ & $\begin{array}{l}-0.005 \\
0.004 \\
(0.17)\end{array}$ & $\begin{array}{l}-0.005 \quad \pm \\
0.006 \\
(0.39)\end{array}$ & $\begin{array}{l}0.002 \\
0.008 \\
(0.82)\end{array}$ & $\begin{array}{l}0.022 \\
1.570 \\
(0.41)\end{array}$ & $\begin{array}{l}0.35 \\
0.765 \\
(0.19)\end{array}$ & $\begin{array}{l}0.014 \\
0.012 \\
(0.24)\end{array}$ & $\begin{array}{l}-0.017 \quad \pm \\
0.027 \\
(0.54)\end{array}$ & $\begin{array}{l}0.010 \\
0.032 \\
(0.71)\end{array}$ & $\begin{array}{l}-0.070 \\
0.042 \\
(0.09)\end{array}$ \\
\hline
\end{tabular}

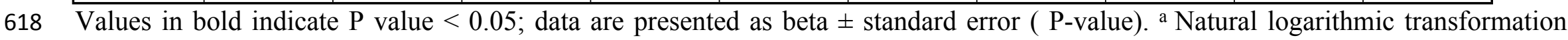

619 applied. ${ }^{\mathrm{b}}$ SNP analyzed under the dominant model. 
Table 3. Association between 6 genetic markers of inflammation and 8 binary metabolic traits.

\begin{tabular}{|c|c|c|c|c|c|c|c|c|}
\hline & $\begin{array}{l}\text { Normal } \\
\text { weight vs. } \\
\text { obese }\end{array}$ & $\begin{array}{l}\text { Normal weight } \\
\text { vs. overweight } \\
\text { and obese }\end{array}$ & Hypertension & Hyperglycemia & Dyslipidemia & $\begin{array}{l}\text { Type } 2 \text { diabetes } \\
\text { family history }\end{array}$ & $\begin{array}{l}\text { Hypertension } \\
\text { family history }\end{array}$ & $\begin{array}{l}\text { Overweight } \\
\text { obesity family } \\
\text { history }\end{array}$ \\
\hline $\begin{array}{l}\text { rs1137101 } \\
(L E P R)\end{array}$ & $\begin{array}{l}0.052[0.886- \\
1.253](0.56)\end{array}$ & $\begin{array}{l}1.004 \quad[0.867- \\
1.162](0.96)\end{array}$ & $\begin{array}{l}1.415 \\
2.562](0.25)\end{array}$ & $\begin{array}{l}0.774 \quad[0.505- \\
1.186](0.24)\end{array}$ & $\begin{array}{l}0.995 \quad[0.853- \\
1.161](0.95)\end{array}$ & $\begin{array}{l}0.883 \quad[0.706- \\
1.105](0.28)\end{array}$ & $\begin{array}{l}0.861 \quad[0.707- \\
1.049](0.14)\end{array}$ & $\begin{array}{l}0.925 \quad[0.799- \\
1.072](0.30)\end{array}$ \\
\hline $\begin{array}{l}\text { rs7305618 } \\
(H N F 1 A)\end{array}$ & $\begin{array}{l}0.849[0.652- \\
1.106](0.23)\end{array}$ & $\begin{array}{l}0.879 \quad[0.704- \\
1.097](0.25)\end{array}$ & $\begin{array}{l}0.732 \quad[0.263- \\
2.038](0.55)\end{array}$ & $\begin{array}{l}0.938 \quad[0.485- \\
1.816](0.85)\end{array}$ & $\begin{array}{l}0.871 \quad[0.688- \\
1.102](0.25)\end{array}$ & $\begin{array}{l}1.347 \quad[0.988- \\
1.837](0.06)\end{array}$ & $\begin{array}{l}1.389[1.054- \\
1.829](0.02)\end{array}$ & $\begin{array}{l}1.050 \quad[0.841- \\
1.311](0.67)\end{array}$ \\
\hline $\begin{array}{l}\text { rs1800629 } \\
(T N F A)^{\mathrm{a}}\end{array}$ & $\begin{array}{l}1.175[0.767- \\
1.799](0.46)\end{array}$ & $\begin{array}{l}1.111 \quad[0.767- \\
1.609](0.58)\end{array}$ & $\begin{array}{l}1.110 \quad[0.260- \\
4.736](0.89)\end{array}$ & $\begin{array}{l}0.793 \quad[0.244- \\
2.576](0.70)\end{array}$ & $\begin{array}{l}1.084 \quad[0.738- \\
1.592](0.68)\end{array}$ & $\begin{array}{l}0.652 \quad[0.336- \\
1.266](0.21)\end{array}$ & $\begin{array}{l}0.553 \quad[0.300- \\
1.018](0.06)\end{array}$ & $\begin{array}{l}1.020 \quad[0.702- \\
1.482](0.92)\end{array}$ \\
\hline $\begin{array}{l}\text { rs1800896 } \\
(I L-10)\end{array}$ & $\begin{array}{l}1.011[0.825- \\
1.239](0.92)\end{array}$ & $\begin{array}{l}1.050 \quad[0.883- \\
1.249](0.58)\end{array}$ & $\begin{array}{l}0.827 \quad[0.393- \\
1.743](0.62)\end{array}$ & $\begin{array}{l}1.348 \quad[0.834- \\
2.180](0.22)\end{array}$ & $\begin{array}{l}1.041 \quad[0.868- \\
1.238](0.67)\end{array}$ & $\begin{array}{l}1.060 \quad[0.813- \\
1.383](0.67)\end{array}$ & $\begin{array}{l}0.991 \quad[0.785- \\
1.253](0.94)\end{array}$ & $\begin{array}{l}1.104 \quad[0.927- \\
1.314](0.27)\end{array}$ \\
\hline $\begin{array}{l}\operatorname{rs1800871} \\
(I L-10)\end{array}$ & $\begin{array}{l}0.929[0.778- \\
1.108](0.41)\end{array}$ & $\begin{array}{l}0.962 \quad[0.827- \\
1.118](0.61)\end{array}$ & $\begin{array}{l}0.851 \quad[0.457- \\
1.584](0.61)\end{array}$ & $\begin{array}{l}1.152 \quad[0.750- \\
1.769](0.52)\end{array}$ & $\begin{array}{l}0.944 \quad[0.805- \\
1.107](0.48)\end{array}$ & $\begin{array}{l}1.015 \quad[0.807- \\
1.277](0.90)\end{array}$ & $\begin{array}{l}0.876 \quad[0.714- \\
1.075](0.20)\end{array}$ & $\begin{array}{l}0.906 \quad[0.779- \\
1.054](0.20)\end{array}$ \\
\hline $\begin{array}{l}\text { rs1862513 } \\
(\text { RETN })\end{array}$ & $\begin{array}{l}0.785[0.585- \\
1.052](0.11)\end{array}$ & $\begin{array}{l}0.932 \quad[0.736- \\
1.180](0.56)\end{array}$ & $\begin{array}{l}1.065 \quad[0.416- \\
2.726](0.90)\end{array}$ & $\begin{array}{l}0.677 \quad[0.310- \\
1.477](0.33)\end{array}$ & $\begin{array}{l}0.941 \quad[0.733- \\
1.209](0.64)\end{array}$ & $\begin{array}{l}1.135 \quad[0.801- \\
1.609](0.48)\end{array}$ & $\begin{array}{l}0.981 \quad[0.713- \\
1.350](0.91)\end{array}$ & $\begin{array}{l}0.984 \quad[0.777- \\
1.246](0.89)\end{array}$ \\
\hline
\end{tabular}

Values in bold indicate $\mathrm{P}$ value $<0.05$; data are presented as beta [confidence interval] ( P-value). ${ }^{\text {a }}$ SNP analyzed under the dominant 627 mode. 